\title{
Dobra Nowina w środkach spotecznego przekazu pod red. Henryka Sławińskiego, Ancilla Verbi, t. 10, Kraków 2020
}

Kościół nie od dzisiaj dostrzega konieczność odnowy swojej działalności ewangelizacyjnej. Zamysł ten ożywiał Ojców II Soboru Watykańskiego i był wyraźnie zaznaczony w nauczaniu oraz posłudze apostolskiej trzech ostatnich poprzedników obecnego Biskupa Rzymu. Papież Franciszek także podejmuje to zagadnienie. Już Paweł VI zauważył, że dzisiaj jest coraz więcej osób, które „czują potrzebę poznania Jezusa Chrystusa inaczej im przedstawianego, aniżeli zwykło się przedstawiać dzieciom w nauce religii oraz wielu innym" (EN 52). Dlatego Kościół musi niestrudzenie szukać odpowiednich środków i języka, aby skutecznie głosić powszechne powołanie każdego człowieka do zbawienia. Dzisiejsi świadkowie Ewangelii powinni wykorzystywać $\mathrm{w}$ przepowiadaniu i duszpasterstwie potencjał starych i nowych środków komunikacji, a nade wszystko wskrzesić w sobie odwagę do zadomowienia się na „nowych areopagach” oraz odnajdywania środków i sposobów, by „również w tych ultranowoczesnych miejscach było obecne dziedzictwo edukacji i mądrości, które przechowuje tradycja chrześcijańska" (RM 37).

Opublikowana niedawno książka pod red. ks. Henryka Sławińskiego, pt. Dobra Nowina $w$ środkach spolecznego przekazu stanowi jeszcze jeden dowód na to, że duszpasterze, osoby życia konsekrowanego oraz wierni świeccy potrafią wskrzesić w sobie odwagę do wykorzystywania zarówno starych, jak i nowych, a nawet ultranowoczesnych środków komunikacji w działalności ewangelizacyjnej. Świadczy o tym problematyka poszczególnych artykułów tworzących tę publikację: trwała rola i znaczenie słowa pisanego w dziele ewangelizacji za 
pomocą multimediów, przekaz Ewangelii i formacja chrześcijańska w radiu, telewizji, na ekranie, w Internecie czy mediach społecznościowych.

Dobrze się stało, że poszczególne teksty poprzedzono wprowadzeniem na temat istoty ewangelizacji. Kościół bowiem, poszukując odpowiedzi na pytanie, czy i w jakim zakresie pojawiające się coraz to nowe i nowocześniejsze środki społecznego przekazu mogą być narzędziami i przekaźnikami prawd ewangelijnych, zaczynał i zaczyna zawsze od uświadomienia sobie na nowo, że najważniejszym celem ewangelizacji jest doprowadzenie każdego człowieka do spotkania z Chrystusem, który jest główną treścią głoszonej Dobrej Nowiny. Autorzy niniejszej publikacji o tym nie zapomnieli. Ukazując zarówno ogromne możliwości, jak i pewne ograniczenia nowych mediów w głoszeniu światu Ewangelii, stawiali sobie przede wszystkim pytanie, czy z tych niezliczonych tekstów, obrazów i dźwięków wypełniających dziś pisma, radio, telewizję, film i Internet wyłania się rzeczywiście twarz Chrystusa i daje się słyszeć Jego głos (por. Jan Paweł II, Orędzie na 36. Światowy Dzień Środków Społecznego Przekazu 2002 r., 6). Już z tego względu warto było tę książkę wydać i warto po nią sięgać.

ks. dr hab. Adam Kalbarczyk ${ }^{1}$, prof. UAM Uniwersytet im. Adama Mickiewicza w Poznaniu Wydział Teologiczny

\section{Good News in the Mass Media}

\section{Summary}

The Church must tirelessly seek appropriate means and language to effectively proclaim every person's universal vocation to salvation. Today's witnesses to the Gospel should use the potential of old and new means of communication in preaching and ministry. Above all, they should revive in themselves the courage to settle on 'new areopaguses'. The most important goal of evangelization is to bring every person to an encounter with Christ, who is the main content of the proclaimed

1 Adam Kalbarczyk - priest of the Archdiocese of Poznan, PhD with a postdoctoral degree in theology, Associate Professor of homiletics at the Faculty of Theology of Adam Mickiewicz University in Poznań; member of the Society of Friends of Science in Poznań; German philology specialist, translator; author of several books and articles on pastoral theology and theology of preaching; his interests focus on homiletic rhetoric, the so-called 'children's theology', the relationship between the theatre and preaching, the ministry of the word by the laity, and the history of Protestant preaching in the period of Lutheran orthodoxy; e-mail: adamkal@amu.edu.pl. ORCID: 0000-0002-3749-2497. 
Good News. The authors of this monograph did not forget about it. By showing both the enormous possibilities and certain limitations of the new media in proclaiming the Gospel to the world, they first asked themselves whether those countless texts, images and sounds that fill today's periodicals, radio, television, film truly reflect the face of Christ and let His voice be heard.

\section{Keywords}

Good News, evangelization, mass media

\section{Słowa kluczowe}

Dobra Nowina, ewangelizacja, mass media 